\title{
SOVIET CONSUMER GOODS ADVERTISING: PROPAGANDA AND CONSUMPTION IN THE 1950S-1980S IN LITHUANIA
}

\author{
Brigita Tranavičiūtè \\ (Kaunas University of Technology)
}

\begin{abstract}
This article presents an analysis of Soviet consumer advertising as a means of Soviet propaganda in order to form a public consumer culture. Material from Soviet advertising institutions in Lithuania, creators of advertisements from the second half of the 20th century, and archival and published sources, has been used to achieve this aim. In order to show the propaganda goal of Soviet advertising, periodical publications from the period have also been analysed. Based on socialist propaganda arguments formulated in various sources, the author conducts an analysis of the functions of Soviet advertising and a comparative analysis of Soviet and Western advertising in the article. After defining the functions of Soviet advertising, one of the aims of this article is to determine the influence of Soviet advertising on the formation of Soviet consumer culture.
\end{abstract}

KEYWORDS: Soviet advertising; consumption; consumer culture; propaganda.

\section{Introduction}

Modernisation trends in Soviet society in the 1950s and 1960s are associated with the process of de-Stalinisation, industrialisation, technological progress, rapid urbanisation, consumption, etc. These trends were developed not just by the general policies of the Soviet Union, based on which the concept of 'The Thaw' has become used in historiography, but also the goal to create a unique, that is, communist, society. ${ }^{1}$ When Nikita Khrushchev came into power in the Soviet Union, social reforms were introduced to encourage modernisation processes in Soviet society.

Some social modernisation processes were determined by the natural economic development of the Soviet Union, which improved society's material potential, and encouraged a higher level of consumption and

${ }^{1}$ V.M. Zubok, A Failed Empire: The Soviet Union in the Cold War from Stalin to Gorbachev (Chapel Hill, 2007), pp. 164, 177. 
better living conditions. However, the Soviet government took some of these modernisation processes, which included the education of society based on socialist principles, into its own hands. Various perspectives are taken in historiography when looking at the issue of the modernisation of Soviet society. According to some authors, alongside encouraging the processes of urbanisation and industrialisation, the Soviet government also aimed to educate society, so that a new cultural person would be created, one who would be prepared to take on the challenges of urbanisation and industrialisation. ${ }^{2}$ Thus, part of the modernisation of Soviet society was related to its level of consumption, which not only had to meet but also exceed the consumption standards of Western society. This goal was set when the Soviet Union adopted a policy of competing against Western states, brought on by the Cold War, when the competition in the fields of technology and armaments was extended to everyday life in Soviet society.

It is no accident that one of the main aspects of the modernisation of Soviet society is the improvement of its material and everyday living conditions. According to Susan E. Reid, in the context of Cold War tensions, the improvement of living conditions in Soviet society and the increased scale of use of household appliances in the 1960s spurred on the modernisation and formation of a consumer society among the Soviet people. ${ }^{3}$ The author notes that some of the main elements of the modern Soviet way of life were the acquisition of more spacious apartments that were better suited to people's needs, and the application of technological advances in their homes and daily lives. ${ }^{4}$

Natalya Chernyshova noticed similar trends, though under Leonid Brezhnev, where the increased scale of property acquisition among the population and higher incomes in the Soviet Union prompted people to buy even more consumer goods to improve their daily lives, products which they treated as forms of expression of culturedness, a higher status and a modern lifestyle. ${ }^{5}$ Unlike during the period of

2 J. Gronow, S. Zhuravlev, Fashion meets socialism: fashion industry in the Soviet Union after the Second World War (Helsinki, 2015), p. 11.

${ }^{3}$ S.E. Reid, 'This is tomorrow! Becoming a consumer in the Soviet sixties', in: The Socialist Sixties: Crossing Borders in the Second World eds. A.E. Gorsuch, D.P. Koenker (Bloomington, Indiana, 2013), pp. 25-65.

${ }^{4}$ S.E. Reid, 'Cold War binaries and the culture of consumption in the late Soviet home', in: Journal of Historical Research in Marketing, vol. 8, no 1 (2016), pp. 17-43.

5 N. Chernyshova, 'Consuming technology in a closed society: household appliances in Soviet urban homes of the Brezhnev era', in: Ab Imperio, no 2 (2011), pp. 188-219. 
Khrushchev's rule, when a vision of society's modernisation was developed through the prism of collectivism, the idea of socialist modernity in the Brezhnev period was noted for its greater individualism, and was more focused on the improvement of social status and increasing opportunities for consumption. ${ }^{6}$

Similar trends and results in the modernisation of Soviet society can be seen in Lithuanian historiography. According to the historian Vilius Ivanauskas, despite the totalitarian system, Soviet modernisation in Lithuania laid the foundations for the formation of an urban culture and an intellectual class, as well as more prominent expressions of consumption. ${ }^{7}$

However, the illusion of better opportunities for consumption was diminshed by the inadequate range of products available. Society's disappointment in this area was apparent through the search for informal means of consumption: the widespread use of blat (favours), the services of speculators, the pilfering of goods from factories, etc. Even the Soviet elite, who had considerably better opportunities for consumption, made use of any chances they had to acquire foreign products that guaranteed prestige. ${ }^{8}$

All of these elements relating to the modernisation of Soviet society were reflected in one way or another in the consumer culture that was being formed, whose development was defined based on criteria set by the government, such as rational consumer needs, avoiding excessive consumption, the requirements of Soviet taste, etc. Once consumer needs had become one of the elements of socialist modernisation, the development of the Soviet industrial sector to produce these consumer goods, as well as ways in which the goods were offered to consumers, became a priority. Even under the prevailing conditions of shortages of certain goods, it was acknowledged that advertising was nevertheless required, although it was not meant to encourage excessive consumption, but rational purchasing habits, and to help highlight the achievements of Soviet industry and trade.

${ }^{6}$ N. Chernyshova, Soviet consumer culture in the Brezhnev era (London, New York, 2013), p. 10.

7 V. Ivanauskas, 'Sovietmečio laimèjimai Lietuvoje ir jų interpretacijos: nomenklatūros veiklos vertinimas nacionaliniu aspektu', in: Darbai ir dienos, no 52 (2009), p. 109.

${ }^{8}$ See: V. Ivanauskas, Lietuviškoji nomenklatūra biurokratineje sistemoje: tarp stagnacijos ir dinamikos 1968-1988 m. (Vilnius, 2011), p. 430. 
Based on this, the aim of this article is to analyse Soviet advertising as one of the main measures used for the spread of socialist propaganda and the formation of a consumer culture in Soviet society in Lithuania in the 1950s to 1980s. The following objectives were set: 1) to analyse and describe the process of creating Soviet advertising, and the dynamics of advertising content from the 1950s to 1980 s in Lithuania; 2) to analyse Soviet advertising as a Soviet propaganda measure; and 3) to analyse and determine how Soviet advertising was intended to form a consumer culture in Soviet society. Taking into account the fact that this topic has hardly been studied in Lithuanian historiography, descriptive, analytical and comparative methods were used.

Several groups of sources were chosen to prepare this article. The choice of suitable research sources was determined by the fact that product advertisements are analysed in the article, leaving the service sector outside the research. It is also important to note that the main focus in the article is on two types of product advertising: in the press, and in shops. Taking a deeper look at the creation and content of Soviet advertising, the issue of advertising and socialist propaganda, and separate aspects of Soviet consumer culture in Lithuania in the 1950s to 1980s, Soviet-era specialised and periodical publications, and various visual material, are mostly used.

One of the main published sources used in the research is the advertising circular-collection of articles published by the Lithuanian Consumers' Cooperatives Union Kooperatininkas $\backslash$ (The Cooperativist). This publication was in effect aimed at and accessible only to specialists who worked in the trade and public dining sectors. It featured articles with lightly veiled hints at propaganda that would help specialists working in these sectors understand how to advertise their products. The Soviet press also makes up a significant part of the sources used in this study: Kauno tiesa (Kaunas Truth), Švyturys (The Lighthouse), Tarybine moteris (Soviet Woman), Jaunimo gretos (Among Youth), and Komunistas (The Communist). Their articles are used to analyse socialist propaganda and consumer culture. Some of the sources were unpublished: documents from the LSSR Ministry of Trade in the Lithuanian Central State Archives (LCVA), that were used to identify the creation process of Soviet advertising and its impact on consumption levels. 


\section{The creation and content of Soviet advertising in Lithuania from the 1950s to the $1980 \mathrm{~s}$}

Due to the Soviet government's persecutions and policies of terror, the Lithuanian population experienced many economic difficulties in the 1940s and early 1950s. The all-encompassing governance of the state could not satisfy the basic consumer needs of society. It was probably no accident that any mention of consumer problems arising as a result of the political leadership was strictly avoided in the press in the 1950s, and all trade-related shortages were blamed on speculators and dishonest traders. ${ }^{9} \mathrm{~A}$ news item printed in the magazine Švyturys about how buyers could not find furniture for their new apartments received the response that the furniture industry

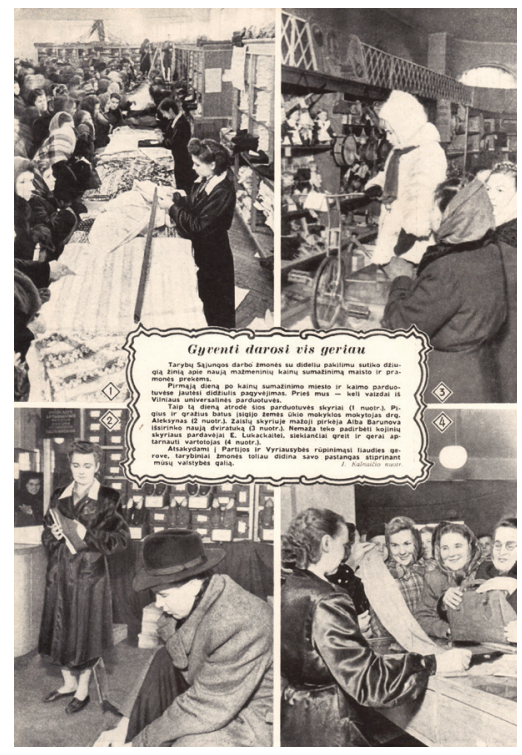

Propaganda advertisement about the great number of goods in shops.

Švyturys, 1950, no 5 . was producing more and more goods, but 'Dishonest types stand around all day in shops and grab the best pieces as soon as they appear.' 10

Until the end of the 1950s, there was practically no network of institutions in Lithuania that handled advertising. However, regardless of this, certain forms of advertising based on examples sent from Moscow were used, which were adapted to Lithuanian conditions. With no opportunity to use other types of advertising, for some time press advertisements were the only form of more significant advertising. One of the main reasons for advertising products in the press was the need to hide the actual economic situation and the constant shortage of goods. An increase in advertising was especially noticeable before socialist celebrations, days which were meant to confirm the achievements of the socialist order. The press formed an optimistic image of the wider choice of products, the reduced prices, the diminishing shortages of products, and the better provision of goods for society.

${ }^{9}$ A. Surminas, 'Už tikrai kultūringą prekybą', in: Tarybinè Klaipéda, 26 December 1952.

10 'O teisus vis dèlto pirkejjas', in: Švyturys, no 3 (1959), p. 17. 


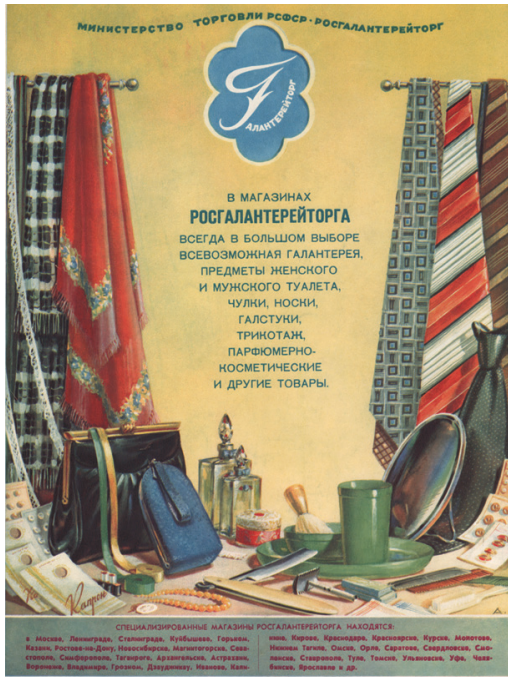

Haberdashery goods advertisement featured in the Russian-language magazine Ogoniok. Ogoniok, 1952, no 39.

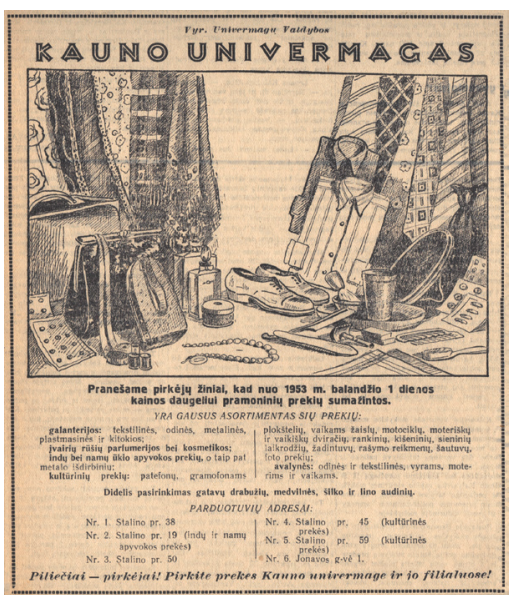

Advertisement for the Kaunas Department Store. Kauno tiesa, 1 April 1953.
In analysing product advertising in the Lithuanian press from the $1950 \mathrm{~s}$, we can see that periodical or store press advertisements prevailed, inviting consumers to buy various products, of which there were allegedly plenty in the shops, and which were affordable to everyone. In trying to demonstrate the positive side of the Soviet regime's economic policy in Lithuania, advertisements highlighted the fact that everything was done for the welfare of the working people, prices were being reduced, more products were available in the shops, and so on. ${ }^{11}$

In the earliest product advertisements in the press, there was actually little direct advertising of specific goods, but plenty of political content and justification of the Soviet government's actions. Advertisements printed in Švyturys contained a great deal of political propaganda glorifying the government's efforts in providing the public with goods. One of the illustrated advertisements announced: 'The working people of Kaunas, as in the whole of the Soviet Union, with great gratitude to the Bolshevik Party, welcomed the reduction of product prices. In the photograph, we see Kaunas

${ }^{11}$ Vilniaus universalinès parduotuvès ir Kauno maisto prekybos parduotuvès reklama, in: Švyturys, no 5 (1950). 
residents choosing food products from Maistprekyba store No 313.' ${ }^{\prime 2}$

Attempts were made to focus the attention of potential customers on generalisations about 'a better life and a larger range of products', and the organisations responsible for the choice of goods in shops. A number of advertisements like this appeared in the newspapers of Lithuania's largest cities. For example, an advertisement by a Kaunas industry trade shop printed in the newspaper Kauno tiesa invited customers to buy a wide range

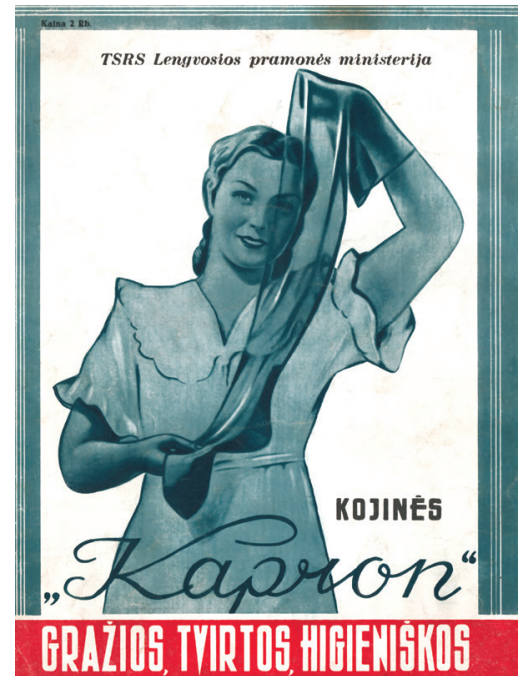

Nylon sock advertisement. Tarybine moteris, 1953, no. 1 . of products at reduced prices. ${ }^{13}$

Some advertisements tried to entice customers into visiting food and specialised shops, and to come to display-sales organised in shops. ${ }^{14}$

For some time, unspecified product advertising was an excellent basis for advertising sent from Moscow to be adapted to suit Soviet Lithuania. The most common form of advertising that was adapted here from the Moscow press advertised specific kinds of products or various goods. Examples of advertising were reprinted in several magazines and newspapers. For example, an advertisement for nylon socks put out by the USSR Ministry of Light Industry in 1952 was adapted and printed in a 1953 issue of $\breve{S}$ vyturys ${ }^{15}$ magazine, and was even adapted several times in advertising for the Koton and Silva state-run sock factories that appeared in the Kauno tiesa newspaper. ${ }^{16}$ Haberdashery product motifs that were printed in the

12 Ibid.

${ }^{13}$ Kauno pramonès parduotuvių reklama, in: Kauno tiesa, 14 April 1954.

${ }^{14}$ Kauno maisto prekybos reklama Naujiems metams, in: Kauno tiesa, 26 December 1950; Pirkejų žiniai! Reklama apie Kaune atidarytą specializuotą indų parduotuvę, in: Kauno tiesa, 26 November 1950; Audinių parodos-pardavimo reklama Vilniuje, in: Vakarinés naujienos, 24 July 1958.

${ }^{15}$ Kaproninių kojinių reklama, in: Švyturys, no 3 (1953).

16 Valstybinio kojinių fabriko Koton reklama, in: Kauno tiesa, 25 October 1953; Valstybinio kojinių fabriko Silva reklama, in: Kauno tiesa, 20 July 1953. 


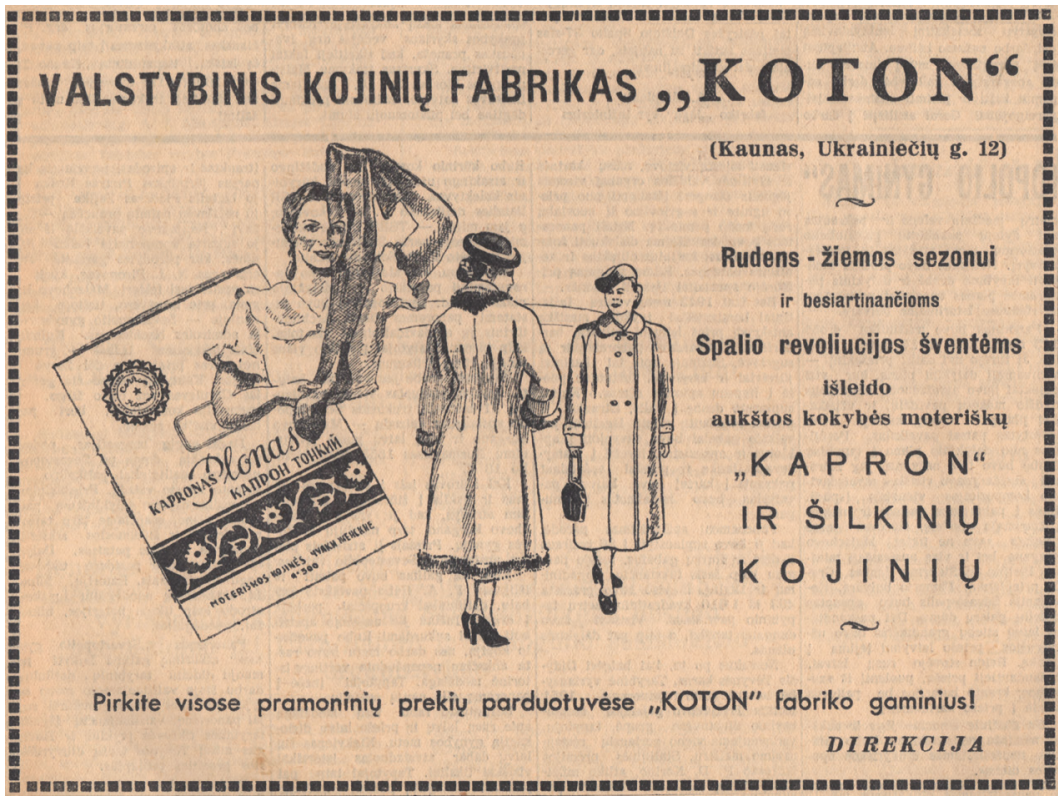

Advertisement for the Koton State Sock Factory.

Kauno tiesa, 20 October 1954.

Russian magazine Ogoniok ${ }^{17}$ in 1952 were used in advertising for the Kaunas department store published in Kauno tiesa in 1953. ${ }^{18}$ There were also other versions of how advertising for other products was adapted to local Lithuanian conditions. ${ }^{19}$

Specific advertising was more characteristic of products manufactured in various factories. It is likely that the goal here was to make an impression on consumers not just about the goods themselves, but also about the achievements of Soviet industry. Press advertisements constantly highlighted both the growing scale of production and the major reconstruction and modernisation of the equipment of former enterprises, made possible through the actions of the Soviet government. The Drobè, Liteksas, Audimas, Koton and Kauno audiniai textile factories, and others like these

${ }^{17}$ Galanterijos prekių reklama, in: Ogoniok, no 39 (1952).

${ }^{18}$ Kauno universalinès parduotuvès reklama, in: Kauno tiesa, 1 April 1953.

${ }^{19}$ Medvilninių audinių reklama, in: Švyturys, no 11 (1953); Medvilninių audinių reklama, in: Tarybinè moteris, no 6 (1953); Vaikiškų batų reklama, in: Švyturys, no 16 (1953); Vaikiškų batų reklama, in: Tarybine moteris, no 8, (1953). 


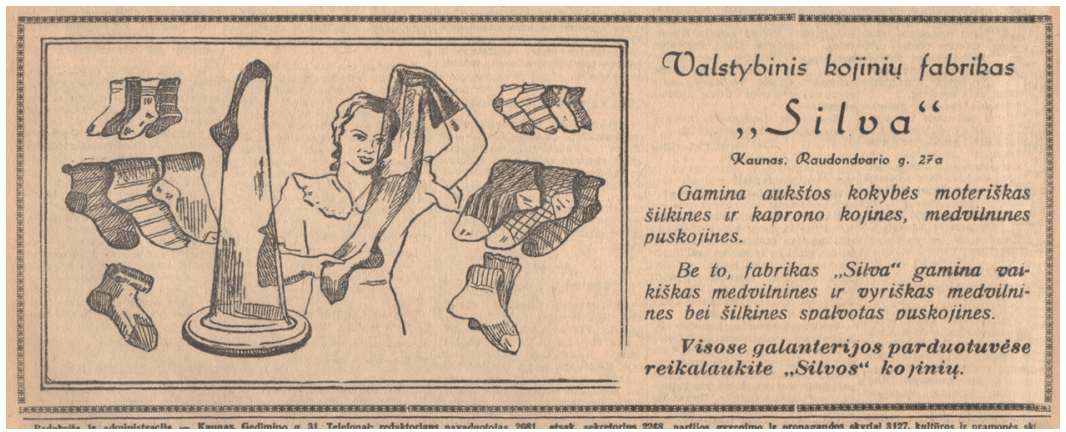

Advertisement for the Silva State Sock Factory,

Kauno tiesa, 28 July 1953.

that consumers had some affection for, having been established in the interwar years and yet were allegedly modernised thanks to Soviet efforts, were meant to completely confirm the achievements of Soviet industry. Below is an excerpt from the Soviet press about the increased productivity of factories:

Production from the Drobè woollen textiles factory, as yet not working to full capacity, has grown immensely. In the bourgeois times, working at full capacity with 49 weaving looms, this factory only managed to produce 1,000 metres of fabric a day. The Soviet Drobe factory meanwhile, working with a quarter fewer looms, already produces 300 metres of fabric a day more. In addition, the current factory's production is of a much better quality. Production from the Jega, Silva and Koton sock and knitwear factories has also increased manifold. ${ }^{20}$

The product advertising by factories was itself much more informative than unspecific cases of product advertising. An advertisement for the Audimas State Tricot Factory published in 1954 presented goods for the autumn-winter season, described as being of high quality, and offered a wide range for women, men and children. ${ }^{21}$ Another invites consumers to purchase a processed pork product from the Supreme Meat-Fish Trading Vilnius Refrigerated Goods Manufactuer, with a taste equal to that of a delicatessen, and which requires less effort in the kitchen and is less expensive. 22

${ }^{20}$ R. Naikauskas, 'Tekstilès ir trikotažo pramonès augimas', in: Kauno tiesa, 9 February 1951.

21 Valstybinio trikotažo fabriko „Audimas“ reklama, in: Kauno tiesa, 26 September 1954.

${ }^{22}$ Vyriausiosios mėsos-žuvies prekybos Vilniaus šaldytuvų kombinato bekono reklama, in: Vakarinés naujienos, 3 September 1958. 


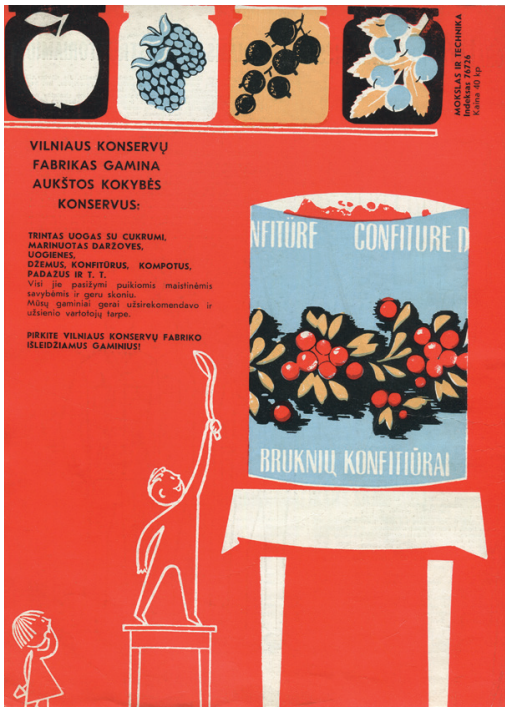

Advertisement for products from the Vilnius Preserves Factory.

Mokslas ir technika, 1967, no 2.

The process of creating Lithuanian advertising gained an institutional basis in 1958 when an advertising department started working under the LSSR Minsitry of Trade, which coordinated the work of agencies responsible for the advertising trade and public dining. ${ }^{23}$ This department usually first received instructions and visual material from Moscow, which depicted how advertising copy should sound, and how the advertisement, shop windows and product arrangement should look. Booklets, photographs and catalogues with shop window arrangements were compiled based on the work of shop window outfitters from Moscow and Leningrad (St Petersburg). ${ }^{24}$ The creation, realisation and control process of advertisements was placed in the hands of several different instutions and organisations at a republic, city and individual level, whose combined actions had to guarantee that Soviet advertising would work. In fact, until the 1990s, the spread and activities of the institutional network responsible for advertising was quite a problem: institutions were established in a chaotic manner, their functions were not coordinated, and they often duplicated each other's work.

The level of informativeness and artistry of Soviet advertising grew between the 1960s and the 1980s: copy was aimed more at the promotion of a specific product, illustrations were more inventive, and there were more colour advertisements and photographs in magazines. Advertisements for food and industrial goods were published in magazines and newspapers that had the highest circulations. Advertising for products from the largest factories dominated, especially goods that became Soviet or international expo winners.

${ }^{23}$ LCVA LSSR Ministry of Trade, f. R-754, ap. 4, 1. 48.

${ }^{24}$ Сборник практических указаний по организации торговой рекламы ( Госторгиздат, 1957), pp. 1-21. 
Food industry advertising was noted for its educational function, whereby it sought to introduce new food products to consumers, giving short instructions on how they could be served or prepared. These advertisements highlighted the specifically positive effects of a product on consumers' health. For example, the Vilnius Preserves Factory announced that their products were 'noted for their excellent nutritional quality and fine taste. Our products have been acclaimed among foreign consumers as well. Buy products from the Vilnius Preserves Factory. ${ }^{25}$

Industrial goods were adver-

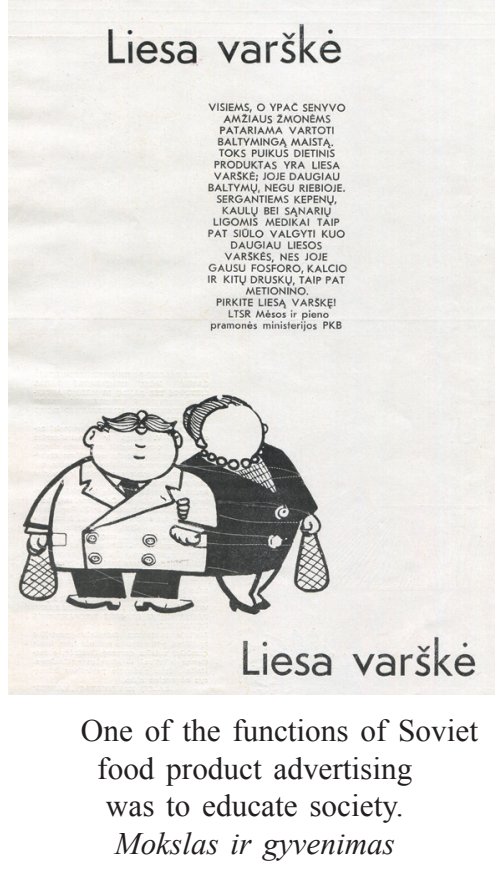
tised in a similar way: they had to provide as much information as possible about the properties of a specific product. These advertisements highlighted the quality and colour of the goods, with buyers being encouraged to follow the producer's recommendations for use.

Due to the development of the network of advertising institutions between the 1960s and the 1980s, much more attention was given to other types of advertising, such as advertisements in shop windows, in showrooms, on stationary stands, and in pamphlets. In addition, other possibilities for advertising increased as the conditions improved for consumerism in Soviet society, and modern self-service shops were built. A space that was better suited to trading increased the possibility to form consumer habits, by using various forms of advertising. The types of advertising that were used in department stores were closely linked to the architecture: architects who designed department stores also had to devise opportunities for product advertising in shop windows and in the shop. Large, spacious and well-lit shop windows had to connect the interior

${ }^{25}$ Vilniaus konservų fabriko gaminių reklama, in: Mokslas ir technika, no 2 (1967). 
trading space with the street, while neatly placed products in shop windows and in shops had to perform the function of advertising. For example, at the Merkurijus department store, built in Kaunas in 1983, the architects paid a lot of attention to product placement, visual information and advertising. ${ }^{26}$

Articles aimed at advertising specialists stated that the function of advertising in the new self-service shops was performed by store signs, the immediate environment, and product arrangement. The buyer first of all had to find a sign with the store's name visible day and night, advertising stands placed at a distance of 300 to 500 metres indicating the shop's location, with additional signage and graphic symbols within the shop itself. The shop's interior, departments, shelf and shop window positioning were considered very important, along with how products were placed in these spaces. The goods themselves, their packaging and labels had to encourage consumers, and inform them about the product's price and properties. ${ }^{27}$

Attempts to influence society's consumption habits using advertising content became one of the most important objectives of Soviet creators of advertising, which is why they had to have a good understanding of the criteria and functions of advertising. Soviet society's belief in improving conditions for consumption had to be bolstered by using propaganda, prompting people to abide by government-regulated consumption directives.

\section{Soviet advertising as a means of spreading socialist propaganda}

The stand-off between the socialist and capitalist systems became an argument for justifying the necessity for advertising in Soviet society. When analysing the arguments for just how necessary Soviet advertising was in a socialist society, we notice that almost all of these arguments are based on principles of socialist ideology, directed towards the aim of creating a communist society. Criticism of Western advertising and the capitalist system served as the best tool for creators of Soviet propaganda for justifying the different nature of Soviet advertising, and its compatibility with the aim of

${ }^{26}$ V. Misevičius, 'Laisvès alèjos puošmena', in: Kauno tiesa, 6 March 1986.

${ }^{27}$ V. Kojokaras, 'Reklamos vaidmuo prekiaujant savitarna', in: Kooperatininkas, no 12 (1973). 
building a socialist society, based on a different relationship with its consumers. ${ }^{28}$

Despite the declared aim of nurturing rational consumption, the Soviet government acknowledged that product advertising was necessary, even in a socialist society, as one of the ways of modernising society. However, it had to be based on socialist principles, and in its form and content it had to broadcast strictly defined information that would arouse interest among consumers in the products of Soviet industry, but not to create a need for excessive consumption. In order to justify the different nature of Soviet advertising, and create the impression that it was morally superior, propaganda measures were used to highlight the advantages of Soviet advertising over its Western equivalent. It was claimed that Soviet advertising was not related to competition or to serving the interests of separate enterprises, which is why its content and aesthetics could be formed in a more wholesome way, taking into consideration the requirements of socialism. ${ }^{29}$

Based on the juxtaposition of the socialist and capitalist systems, and seeking to distinguish differences between Soviet and Western advertising, a demonstrative analysis of the latter was conducted to highlight the profit-oriented goals of Western advertising. Soviet advertising, meanwhile, rejected this profit-driven approach, and presented advertising as follows:

'... to accurately, clearly and attractively explain, advise, promote, save people's time, and keep people informed of the latest developments in trade, daily life and science. Ultimately, it is wrong to leave propagandistic-political information to the press, radio and television alone.' 30

The advantage of Soviet advertising over its Western equivalent was based on its unique function in complying with the ideals of socialism. One of the main functions of Soviet advertising was its ideological role. The ideology behind advertising meant that an advertisement had to promote the Soviet way of life, forming value categories, social emotions, customs and traditions that were

${ }^{28}$ For more about advertising provisions in the Soviet Union and in other socialist Eastern and Central European countries, see: P. Hanson, Advertising and Socialism: the Nature and Extent of Consumer Advertising in the Soviet Union, Poland, Hungary and Yugoslavia (Palgrave Macmillan, 1974), pp. 1-14.

${ }^{29}$ I. Laurušas, 'Vilniaus reklama', in: Statyba ir architektūra, no 11, (1968), p. 17.

${ }^{30}$ A. Kazakauskas, 'Informacija ir miesto grožis', in: Tiesa, no 213, 10 September 1972. 
related to political, economic, legal and everyday relations in Soviet society. ${ }^{31}$ The ideological role of Soviet advertising was based on the juxtaposition of the socialist and capitalist systems. In Soviet ideology, the latter system was viewed as immoral and seeking unjustifiably high profits, while the socialist system was seen as meeting consumers' interests, as it did not harbour such aims.

The ideological nature of Soviet advertising was associated with rational consumption. A search for arguments to justify rational consumption and counter Western consumption took place amidst a statement of goals that were quite hard to realise: Soviet advertising had the function not only of economic reform, but also the social reform of its population. ${ }^{32}$ As has been claimed in Soviet propaganda, one of the aims of Soviet advertising was '... to encourage product realisation, to actively impact on consumption among the people, to help form a rational structure of consumption, to educate the population and raise their level of aesthetic awareness, to positively influence the development of people's needs, to help form new and positive needs, and to shake off old, unsuitable needs'. ${ }^{33}$

The elimination of consumerist goals became the main feature of rational consumption to ensure the fostering of certain value provisions in Soviet society, and ultimately, as in other fields, advertising had to aim at the main goal of building a communist society:

' $\ldots$ the objectives of socialist advertising are not only much broader than in the world of private enterprise, they are in principle different. They depend on the unity of economic and ideological objectives. When promoting products, advertising must on occasions "fight" against them, in order to protect people from blind obedience to objects, and from the dictates of a consumer psychology [...] The spiritual values to which our advertising appeals must help to form the communist way of life, and ethical qualities such as friendliness, justice, human dignity, commitment to one's duties, civil activism, and the importance of work.' 34

Ensuring that advertising was humanistic was another function that Soviet advertising definitely had to perform. Based on the humanist function, Soviet advertising had to highlight the qualities of certain goods, their purposes and advantages, encourage personal

${ }^{31}$ В.Г. Тихоновский, Торговая реклама и основы декорирования (Москва, 1987), p. 9.

32 'Reklamos reikšmè', in: Kooperatininkas, no 11 (1975), p. 27.

33 'Prekè, reklama, pirkejas', in: Kooperatininkas, no 9 (1963), p. 1.

${ }^{34}$ I. Kokarevas, 'Reklamos idejiškumas', in: Kooperatininkas, no 11 (1973), p. 4. 
growth, broaden horizons, help put in order the rational handling of the family budget and the economy of time, and to put in place the right skills for socialist cooperation, at the same time as improving the aesthetics of daily life and production. ${ }^{35}$ The humanism of Soviet advertising was related to so-called socialist morality, which was expressed as the provision of reliable and accurate information about a product. ${ }^{36}$ According to the Soviet press, by providing misleading information about a product, creators of advertising were inflicting moral harm on consumers and abusing their trust. In this way, misleading information about products forced consumers not to react to advertising at all, thereby nullifying the work of advertisers. ${ }^{37}$

The reliability criterion of advertising was often described rather illustratively and with propaganda aims. Creators of advertising were always required to ensure that an advertisement was attractive, appealing, tasteful, and most importantly, it had to be accurate. The reliability criterion of advertisng was associated most with clearly indicating the price, and only then the positive properties of the product. Creators of Soviet advertising were often criticised for this; it was alleged that by advertising a product, they were being too clever in accentuating the appeal of a certain product and its other properties, but were failing to indicate its price, because 'By not showing the price, we not only disappoint the consumer, but literally drive them away: "Apparently this isn't for everyone, if even the price is not shown." 38

Soviet advertising also had to be competent; this meant that product advertising had to be based on the latest results of Soviet scientific research, and to reflect different disciplines, such as the arts, psychology, sociology, pedagogy, medicine and design. Basing Soviet advertising on scientific results accentuated its advantages over Western advertising, which Soviet propaganda accused of incompetency: it was excessive, contradictory and disorientating, making consumers choose a product under the effect of psychological coercion. ${ }^{39}$ Soviet advertising, on the other hand, was allegedly based on scientific research, it allowed consumers to find out where

\footnotetext{
35 В.Г. Тихоновский, Торговая реклама и основы декорирования, р. 9.

36 'Reklamos reikšmè', p. 27.

37 'Reklama, vartotojas ir jo teisè', p. 29.

38 A. Gulbinas, 'Kodèl pamirštame tikraji matą?', in: Švyturys, no 11 (1967).

39 'Reklamos reikšmè', p. 27.
} 
a product could be purchased, and it convinced them why a newer version of a product was better than its predecessor, and why consumers might not want to buy a certain product despite knowing its advantages. ${ }^{40}$

The competency of Soviet advertising was closely related to the provision of accurate information about a product and its properties, and justifying its advantages over an older model. Providing information about products in Soviet advertising had to be based on scientific or technologically advanced arguments, with numerous advertising publications being criticised for avoiding basing their advertisements on science or the results of technological progress:

'Let us leaf through one issue of Reklama. The Vilnius Leather Haberdashery Factory has an advertisement for a new handbag. There is a list of what it can hold, and consumers are advised to look for haberdashery products made by this manufacturer at republic haberdashery goods shops and department stores. However, neither the model nor the price is indicated, nor what materials it is made from. But an advertisement must be based on the latest scientific and technical information [...] Or, for example, what would a consumer want to know about a new model of shoe? Naturally, how much more durable it is than earlier models. This is the kind of basic advertising material we are constantly missing. ${ }^{241}$

Soviet propaganda formed the provision that, based on the principle of competency and accurate information about a product, advertising had to inform the consumer about the actual properties of a product to show the consumer its consumption value, provide an accurate and clear characterisation of the product, and indicate how it was used and its distinguishing features. ${ }^{42}$ An example of providing accurate information about a product was a situation where the product itself, its properties and quality would confirm the emotions aroused in the consumer by the adverstisement. More so, based on the principle of accurate advertising information, other aspects which had to be taken into consideration were product demand, production scale and the reduction of production costs. ${ }^{43}$

Publications aimed at creators of Soviet advertising that we analysed show that in Soviet propaganda it was important to highlight

40 V. Šliapentochas, 'Sociologiniai tyrimai ir reklama', in: Kooperatininkas, no 6 (1973), p. 22.

${ }^{41}$ V. Armalis, 'Ar mes vejamės reklamą, ar reklama mus?', in: Tiesa, no 217, 19 September 1984.

42 В.Г. Тихоновский, Торговая реклама и основы декорирования, р. 9.

${ }^{43}$ A. Markevičius, 'Reklama - prekybos šypsena', in: Kooperatininkas, no 8 (1966). 
how an advertisement was linked to consumers' interests; that is, advertising could not be related to profit, or to attempts to convince the consumer of non-existent advantages of a product, which would encourage consumers to purchase as many of the goods as possible unnecessarily. The functions of Soviet advertising were directed at justifying how different it was from Western advertising, explaining it through the prism of socialist ideology, and attributing different aims: to educate the consumer guided by the principles of socialism, and to implement the government's vision of communist society.

\section{Soviet advertising and consumption}

The relationship between product advertising and consumption was deliberated very actively in Soviet ideology, as advertising was viewed as a great risk factor that could arouse unjustifiably strong consumerist trends in Soviet society. This idea was based on the main argument in the contraposition of socialism and capitalism, where Western advertising as a means of boosting product demand among consumers was one of the greatest problems of the capitalist world, ensuring profits for businessmen, exploiting consumers financially, and encouraging unjustified trends in consumption. It is important to note that this criticism was expressed not only in arguments about advertising in both systems, but also in arguments about the differences between the aim of consumerism and consumers' intentions.

Both the essence of Soviet advertising and the consumerist goals of Soviet society had to be aligned with socialist ideology and the goal of creating a communist society. There was no denial that Soviet advertising was aimed at encouraging sales and consumerism. However, unlike Western advertising, the Soviet version had to help form a rational structure of consumerism in the population, educate society, elevate their level of aesthetic appreciation, positively influence the development of society's needs, and help form new positive needs, and shake off older, unsuitable needs. ${ }^{44}$

In socialist ideology, rational consumption was based on a person's awareness of how many material values they needed to have to be able to satisfy their main needs. The need for material values was limited on a moral basis that had to act as a kind of safety-catch, preventing materialism from developing. According to Soviet propaganda, the Communist Party helped a person form the

44 'Prekè, reklama, pirkejas', in: Kooperatininkas, p. 1. 
necessary system of spiritual values, encouraged the kinds of needs that improved character, and eliminated ones that follow 'phenomena foreign to socialism, such as greed, egoism, the cult of things, and trying to be better than one's neighbour, not through work but through luxury. It is clear to all of us that one becomes a slave to things when the scale of needs becomes irrational and foreign to the nature of our socialist society. ${ }^{45}$

Rational norms of consumption were defined, based on a set of consumer products, which comprised a home, household appliances, furniture and household and daily service products, transport, goods for servicing transport, a garage, leisure, travel and sports goods, and spiritual and cultural goods. Out of all of these fields, around 200 kinds of product were recognised as being necessary. ${ }^{46}$ The rational consumption norms and set of necessary products had to be revised periodically, taking into account certain economic and social factors, such as industrial development, the scale of manufacture of products, the size of the population, and incomes. ${ }^{47}$

Irrational consumption was in effect related to the cult of things, or, as was also known, to materialism, which was expressed as the great acquisition of objectively unnecessary things in order to satisfy physical or spiritual needs, or the acquisition of exceptionally luxurious things. Materialism was related both to the excessive hoarding of things and to the hoarding of fashionable or prestigious things, which was expressed primarily through a person's clothing and household.

Soviet propaganda paid considerable attention to describing the psychological profile and behaviour of an irrational consumer. First of all, his personal consumer interests were highlighted, defined as the acquisition of things, the striving for luxury, and the aim of demonstrating these things and luxury to others. Second, the things purchased by the irrational consumer were treated as trivial objects, often described using concepts such as 'wasteful' and 'gaudy'. Third, it was important to demean the irrational consumer's understanding of the value of things, and their relationship with others around them. This meant that anything acquired by an irrational consumer had no spiritual value; it was noted as being of meaningless, friv-

\footnotetext{
${ }^{45}$ A. Sinkevičius, 'Po vartojimo skraiste', in: Komunistas, no 10 (1980), p. 30.

${ }^{46}$ LCVA LSSR Ministry of Trade, f. R-754, ap. 4, b. 3322, 1. 32.

47 Ibid., 1. 1.
} 
olous content that was needed mainly to show off in front of other consumers with similar needs. ${ }^{48}$

When analysing the relationship between an irrational consumer and their acquired things, or the things they aspire to acquire, as it was described in Soviet propaganda, the focus was put on accentuating the constant need for things, and the inability to use one's already-acquired things for no other purpose than to highlight 'alleged' prestige. One article had this to say about irrational consumers: 'Do you think it's easy for him to follow volatile trends in clothing, interiors and household appliances? Every day, new things appear, and one must have them in order to "keep up": to have the newest, the best, the rarest, not to be "like everyone else", but to be better than absolutely everyone else. ${ }^{\prime} 9$

It is important to note that the description of an irrational consumer went far beyond the boundaries of describing the relationship between a person and an object, and was broadened to define a person's values and provisions. The negative provisions of an irrational consumer had to be counterbalanced by the government's principles for rational consumption. As one of the means for the formation of rational consumption, Soviet propaganda had to impart to advertising the role of educating the consumer in aesthetic appreciation, since having seen product advertising created specifically for different products, consumers were meant not only to imagine what the products were for, but also to refine their aesthetic awareness and taste. The choice of an item based almost purely on its functional purpose was considered as confirmation of a consumer's good aesthetic taste, that is, the item had to be convenient to use. ${ }^{50}$ This goal applied especially to the advertising of everyday household goods and clothing, when a consumer had to know what furniture or appliances they would like to see in their home, or what clothing combinations were fashionable and suitable to wear based only on the advertisement. Soviet advertising tried to force its way into other spheres of personal life as well. For example, the advertising of leisure goods aimed to promote relaxation that was interesting, educational and healthy, encouraging consumers to pursue their

${ }^{48}$ A. Kirdeika, 'Miesčioni, koks tavo veidas?', in: Jaunimo gretos, no 1 (1983), p. 23

${ }^{49}$ R. Glinterščik, 'O aš - ne miesčionis?', in: Jaunimo gretos, no 8 (1983), p. 26.

${ }^{50}$ G. Galginaitytè, D. Rinkevičiūtè, 'Skonis reikalingas visur', in: Kooperatininkas, no 11 (1968), p. 9. 
favourite hobbies; while food advertising was meant to encourage people to follow the principles of a healthy diet, etc. ${ }^{51}$

In order to avoid creating an association with consumerism, Soviet advertising was treated as an unavoidable result of industrialisation and specialisation in trade. ${ }^{52}$ Self-service was a new form of trading that started to be implemented from the 1960s, and became very important in this sphere. It was considered to be an advanced way of serving customers. Product advertising was seen as an inseparable aspect of self-service, as once customers had the opportunity to select products themselves, advertisements had to serve as guidelines to form their consumption demands. On the other hand, self-service was also associated with irrational demands of consumption, as the many products placed all around a shop could simply arouse a buyer's desire to buy more than they actually needed, or products that captured consumers' attention through their packaging, placing or variety. ${ }^{53}$

Even though Western advertising was criticised for increasing consumption and materialism in people's buying habits, some of the visual advertising measures, and even attempts at influencing buyers' psychology, were not so different to the methods applied in Soviet countries. Foreign advertising practices started being used in the Soviet Union from the 1960s, when consumer needs started to be taken more into consideration, and attempts started being made to create the impression that Soviet industry was creating more products of better quality. Advertising creation technologies and content formation skills were adopted from socialist countries such as the GDR, Poland and Czechoslovakia, and other specialists from socialist countries, while following Western advertising trends was officially avoided. However, Western advertising was nonetheless occasionally adapted. ${ }^{54}$

Regardless of all the criticism of the goals and content of Western advertising, the visual means of presentation of Western advertising sometimes appeared suitable to creators of Soviet advertising. Staff

51 'Reklamos reikšmè', p. 27.

${ }^{52}$ A. Markevičius, 'Reklama - prekybos šypsena'.

${ }^{53}$ V. Kojokaras, 'Reklamos vaidmuo prekiaujant savitarna', in: Kooperatininkas, no 12 (1973).

${ }^{54}$ For more about Soviet advertising based on the advertising practices in Western and socialist countries, see: J.W. Markham, 'Is advertising important in the Soviet economy?', in: Journal of Marketing, vol 28, no 2 (1964), pp. 31-37; also, E. Ibroscheva, Women, media and femininity in the Balkans: advertising, sex, and post-socialism (Lexington books, 2013), pp. 47-75. 
from the Experimental Container and Packaging Construction Bureau visited Paris in 1969 to analyse shop windows in the city, noting that models of almost all the clothing or shoes in a particular shop would be placed in the shop window, and that besides the products sold in a shop, the front window decoration would also incorporate mirrors, garlands, flowers and ornaments. In addition, the content of a shop window would rotate, depending on the season or the approaching calendar feast. Based on their impressions from Parisian shops, the bureau's staff reached the conclusion that 'In France, as in our country, the purpose of shop windows is the same: to provide information about the products sold within, and to arouse consumer interest. Ingenuity and inventiveness when fitting out shop windows is very important for successful trade. ${ }^{55}$

The visitors from Soviet Lithuania objected to the narrative-inspired shop windows of certain Parisian stores, where mannequins posed as if they were going on holiday or to parties, or participating in weddings, or enjoying sitting at home by an open fire. According to the assessments of the staff of the Experimental Container and Packaging Construction Bureau, 'such temptation, fake allure, the "sweetening" of daily life merely tries to show consumers that that kind of joy can be achieved by the product purchased at this store. ${ }^{56}$ This judgement was based on one of the main arguments in the criticism of Western advertising, the exaggeration of consumerism and materialism in buyers' behaviour.

The practices of advertisers in the GDR, Poland, Hungary and Czechoslovakia, which were closely analysed in the press and in specialist literature, remained the best example for the creators of Soviet advertising. These sources had better opportunities to learn the secrets of advertising from the West. The principle of the advertising concept that was adopted from these countries was that the product was the most important element in advertising, which is why it had to take the prime position, both in shop window arrangements and in other types of advertising, in order to highlight the product itself and its quality. ${ }^{57}$ This suited Soviet creators of advertising very well, as they could not use too much secondary information, or stray too far from Soviet advertising regulations.

55 J. Urbonas, A. Šlikaitè, 'Parduotuvès vitrina', in: Kooperatininkas, no 10 (1969), p. 25.

56 Ibid.

57 ‘Socialistinių šalių prekių reklamos naujovès’, in: Kooperatininkas, no 1 (1964). 


\section{Conclusions}

In the 1950s, advertising became one of the main propaganda measures to justify the Soviet government's actions in economics, by trying to hide the difficult material conditions of the population and the shortages or lack of the most basic necessities. Before a network of Soviet advertising institutions was created in Lithuania, a method of adapting product advertising was applied, where examples of advertising or their motifs sent from Moscow were used. The sudden growth of a network of advertising institutions in Lithuania in the second half of the 20th century did not ensure a smooth process of the creation of advertising, as the limits of the competency of these institutions had not been clearly defined, and there was a lack of advertising material and specialists.

In the socialist system, advertising was treated not only as a form of product supply, but also as a means of propaganda that was meant to form good consumption habits among the population. This goal had to be implemented through the functions of ideology, humanity and competency that were attributed to Soviet advertising, aimed at forming a socialist consumer culture, and highlighting the superiority of Soviet advertising over Western advertising.

Distinguishing the advantages of Soviet advertising over its Western counterpart had to be something of a safety-catch, preventing exaggerated consumerism in Soviet society. People's perception of rational consumption was implemented through advertising content and various forms of advertising, which had to convince consumers of the advantages and the suitability of goods they were intent on buying. The declared goal of creating uniquely Soviet advertising was not achieved, as the creation process of Soviet advertising also relied on advertising practices from the West.

Even though attempts were made to realise the theoretical model of a modern socialist society through the justification of being unique, and based on the principles of socialist ideology, in practice some practical problems nonetheless surfaced. The process of creating Soviet advertising, which had to become a means of encouraging the formation of a modern socialist society in Lithuania in the second half of the 20th century, did not go as smoothly as was hoped. The creation of a completely unique version of Soviet advertising failed, not only because certain Western advertising principles were adapted, but also because the necessity to constantly highlight the differences between Soviet and Western advertising remained. 
Author Details

Dr Brigita Tranavičiūte is a researcher at Kaunas University of Technology's Research Centre for Architectural History and Heritage.

Address: Kaunas University of Technology, K. Donelaičio St. 73, LT-44249 Kaunas, Lithuania.

E-mail: brigita.tranaviciute@ktu.lt

\section{Bibliography}

ARMALIS, Viktoras. 'Ar mes vejamès reklamą, ar reklama mus?', in: Tiesa, no 217, 19 September 1984.

CHERNYSHOVA, Natalya. 'Consuming technology in a closed society: household appliances in Soviet urban homes of the Brezhnev era', in: $A b$ Imperio, no. 2 (2011), pp. 188-219.

CHERNYSHOVA, Natalya. Soviet consumer culture in the Brezhnev era (London, New York: Routledge, 2013).

GALGINAITYTĖ, G., RINKEVIČIŪTĖ, D. 'Skonis reikalingas visur', in: Kooperatininkas, no 11 (1968), p. 9.

'Gera pradžia', in: Kooperatininkas, no 12 (1975), p. 16.

GLINTERŠČIK, Roza. 'O aš - ne miesčionis?', in: Jaunimo gretos, no 8 (1983), p. 26.

GRONOW Jukka, ZHURAVLEV, Sergey. Fashion meets socialism: fashion industry in the Soviet Union after the Second World War (Helsinki: Finnish Literature Society, 2015), p. 11.

GULBINAS, A. 'Kodèl pamirštame tikraji matą?', in: Švyturys, no 11 (1967).

HANSON, Philipp. Advertising and Socialism. The Nature and Extent of Consumer Advertising in the Soviet Union, Poland, Hungary and Yugoslavia (Palgrave Macmillan, 1974).

IBROSCHEVA, Elza. Advertising, Sex, and Post-Socialism. Women, Media and Femininity in the Balkans (Lexington books, 2013).

IVANAUSKAS, Vilius. Lietuviškoji nomenklatūra biurokratineje sistemoje: tarp stagnacijos ir dinamikos 1968-1988 m. (Vilnius: LII leidykla, 2011).

IVANAUSKAS, Vilius. 'Sovietmečio laimejjimai Lietuvoje ir jų interpretacijos: nomenklatūros veiklos vertinimas nacionaliniu aspektu', in: Darbai ir dienos, no 52 (2009), pp. 105-119.

KAZAKAUSKAS, Antanas. 'Informacija ir miesto grožis', in: Tiesa, no 213, 10 September 1972.

KIRDEIKA, Aandrius. 'Miesčioni, koks tavo veidas?', in: Jaunimo gretos, no 1 (1983), p. 23.

KOKAREVAS, I. 'Reklamos idejiškumas', in: Kooperatininkas, no 11 (1973), p. 4. 
KOJOKARAS, Vasilè. 'Reklamos vaidmuo prekiaujant savitarna', in: Kooperatininkas, no 12 (1973).

LAURUŠAS, Ignas. 'Vilniaus reklama', in: Statyba ir architektūra, no 11 (1968), p. 17.

LIUTKEVIČIENĖ, Pranè. 'Reklamos kadrai', in: Kooperatininkas, no 2 (1975), p. 25.

MARKEVIČIUS, A. 'Reklama - prekybos šypsena', in: Kooperatininkas, no 8 (1966).

MARKHAM, W. James.'Is Advertising Important in the Soviet economy?', in: Journal of Marketing, vol. 28, no 2 (1964), pp. 31-37.

MISEVIČIUS, Vilius. 'Laisvès alèjos puošmena', in: Kauno tiesa, 6 March 1986.

NAIKAUSKAS, R. 'Tekstilès ir trikotažo pramonès augimas', in: Kauno tiesa, 9 February 1951.

'Prekè, reklama, pirkèjas', in: Kooperatininkas, no 9 (1963), p. 1.

REID, E. Susan. 'This is Tomorrow! Becoming a Consumer in the Soviet Sixties', in: The Socialist Sixties: Crossing Borders in the Second World, eds. A. E. Gorsuch, D. P. Koenker (Bloomington, Indiana: Indiana University Press, 2013), pp. 25-65.

REID, E. Susan. 'Cold War Binaries and the Culture of Consumption in the Late Soviet Home', in: Journal of Historical Research in Marketing, vol. 8, no 1, pp. 17-43.

'Reklamos reikšmė', in: Kooperatininkas, no 11 (1975), p. 27.

'Reklama, vartotojas ir jo teisé', in: Kooperatininkas, no 9 (1974), p. 29.

SINKEVIČIUS, Apolinaras. 'Po vartojimo skraiste', in: Komunistas, no 10 (1980), p. 30.

'Socialistinių šalių prekių reklamos naujovès', in: Kooperatininkas, no 1 (1964).

SURMINAS, A. 'Už tikrai kultūringą prekybą', in: Tarybine Klaipéda, 26 December 1952.

ŠLIAPENTOCHAS, Vladimiras. 'Sociologiniai tyrimai ir reklama', in: Kooperatininkas, no 6 (1973), p. 22.

URBONAS, Jonas; ŠLIKAITĖ, A. 'Parduotuvès vitrina', in: Kooperatininkas, no 10 (1969), p. 25.

VALIUKEVIČIUS, V. 'Pavasaris Budapešte, o Kaune?', in: Komjaunimo tiesa, no 89, 6 May 1987.

ZUBOK, M. Vladislav. A Failed Empire: the Soviet Union in the Cold War from Stalin to Gorbachev (Chapel Hill: University of North Carolina Press, 2007), pp. 164, 177.

Сборник практических указаний по организащии торговой рекламы (Госторгиздат, 1957).

ТИХОНОВСКИЙ, Г. Владимир. Торговая реклама и основы декорирования (Москва, 1987). 


\title{
SOVIETINE PREKIŲ REKLAMA: PROPAGANDA IR VARTOJIMAS XX A. ŠEŠTAJAME-DEVINTAJAME DEŠIMTMEČIAIS LIETUVOJE
}

\author{
Santrauka
}

\section{BRIGITA TRANAVIČIŪTE்}

Sovietų Sajungos įsitraukimas ị Šaltojo karo su Vakarais varžybas, XX a. 7 dešimtmetyje paskatino pažangos ir pirmavimo siekti ne tik ginklavimosi ar technologijų, bet ir visuomenès vartojimo srityje. Dèl šios priežasties sovietinès valdžios inicijuotas naujas sovietinès visuomenès reformų etapas dalị valdžios veiksmų nukreipe ị gyventojų materialinès ir buitinès padèties sąlygų gerinimą. Pripažinta, jog būtinu sovietinès visuomenès modernizavimo elementu turi būti vartojimo galimybès, prilygstančios Vakarų visuomenèms, tačiau siekta išvengti vakarietiškos visuomenès vartotojiškumo apraiškų. Kaip viena iš sovietinès visuomenès tinkamą vartojimo kultūrą formavusių priemonių pasirinkta prekių reklama, kurios turini siekta suderinti su socializmo ideologijos principais. Sovietinès reklamos naudojimas turèjo ir platesnę reikšmę, nes, būdama viena iš sovietinès sistemos pasiekimų propagandos priemonių, reklama turejo prisidèti prie galutinio komunistinès visuomenès sukūrimo tikslo. 